\title{
Business Education Students' Perception of the Influence of Electronic Learning on Skill Acquisition in Edo State
}

\author{
Dr. (Mrs.) Henrrietta Abhameso OLUMESE \\ Department of Vocational and Technical Education, Faculty of Education, University of Benin, Benin City, Edo \\ State
}

\begin{abstract}
This study examined Business Education Students' Perception of the Influence of Electronic Learning on Skill Acquisition in Edo State. The purpose of this study was to examine Business Education Students' Perception of the Influence of Electronic Learning on Skill Acquisition in Edo State. Three research questions were raised for the study. The questionnaire was used to measure the variables using the sample size of 86 respondents from both UNIBEN and AAU, Edo State. The Cronbach's alpha was used in ascertaining the reliability of the instrument after administering the instrument to 20 business education students who were not part of the sample; and it yielded a coefficient of 0.89. The Statistical Package for Social Science (SPSS) version 22.0 was used in the analysis, frequencies, mean, and standard deviation was used in the analysis. Based on the analysis, it was found that Elearning influences the acquisition of distributive, entrepreneurial and teaching skills. Based on the findings, the researcher concluded that for business education graduates to be able to fit into the modern day offices, there is need for e-learning facilities to be used in training the students.
\end{abstract}

Keywords: business education, distributive skills, entrepreneurial skills, teaching skills and electronic learning

DOI: $10.7176 / \mathrm{JESD} / 10-7-11$

Publication date: April $30^{\text {th }} 2019$

\section{Introduction}

Business education is a programme designed to equip students with the necessary skills and competencies needed in the world of work. Given the present day office innovations, business education students are expected to possess those skills and competencies that will enable them to be gainfully employed in modern day offices after graduation. According to Imeokparia and Ediagbonya (2014), Business education is described as an aspect of education that is geared at equipping the learners (students) with business and education competencies (that is, skills, knowledge and attitude) needed to effectively and efficiently function in the world of work either as an employee or an employer(job/wealth creator). Agwumezie (2013) sees business education as a programme in education that prepares students for entry into and advancement of jobs within the business. Aliyu (2009) described it as a programme one needs to be proud of if properly designed, adequately prepared and religiously harmonized. Aliyu further affirms that business education is an educational programme which involves acquisition of skills, knowledge and competences which makes the recipient/beneficiary proficient. It is an umbrella under which all business programmes take a shield, such as marketing, secretarial studies and accounting. The main objective of business education is to ensure steady supply of business educationists with the needed skills to transform the society.

Etesike (2010) defined a skill as the special ability acquired by training. Skill is thought of as a quality of performance which does not depend solely upon a person's fundamental, innate capacities but must be developed through training, practice and experience (Adeyomo, 2009). Although skill depends essentially on learning and quality education, it also includes the concepts of efficiency and economy in performance.

According to Okorie and Ezeji (2012) the acquisition of the requisite skills is a means of increasing the productive power of any nations. The acquisition of such practical skills in business education is important because when efficient and skilful hands are employed in any fields of human endeavors, high productivity is usually achieved. Some of the notable skills that are acquired in business education programme include distributive/marketing skills, entrepreneurial skills and teaching skills.

Distributive Skills is another skills component of Vocational Business Education programme. The word "distribution" has much to do with exchange of goods and services and as such refers to the various hands and agencies through which commodities pass from the manufacturers to the final consumers (Udo, 2012). The acquisition of marketing skill will further exposed business education students and graduates to the tenets of business and the place of technology in marketing products and satisfying the needs of customers who are the reasons for the continued existence of the business. The technological innovations in business have therefore given more prominence to electronic marketing (e-marketing). The kind of education in place has a significant role to play in the acquisition of this marketing skill.

According to Adeyomo (2009), entrepreneurial skills are skills needed to have to succeed in business, most especially in teaching. The author further stressed that entrepreneurial skills are the basic skills necessary to enable you start, develop, finance and succeed in your own enterprise. Hisrich and Peters (2002) defined entrepreneurial 
skill as the ability to create something new with value by devoting the necessary time and effort, assuring the accompanying financial, psychic and social risks, and receiving the resulting rewards of monetary and personal satisfaction and independence. In a similar vein, Olagunju (2004), defined entrepreneurial skill as the ability of an individual to exploit an idea and create an enterprise (small or big) not only for personal gain but also for social and developmental gain.

Teaching Skills is another valuable business education skills, teaching skill is the acquisition of teaching experience for dissemination of information to recipients, in this case students of business education. According to Okoh, (2003), teaching is an intentional activity or goal - oriented activity in which a teacher is fostering or seeking to foster in a learner (who has voluntarily subjected himself/herself to the teacher).

For these skills to be acquired there is need for the utilization of technology, with the advancement in information technology in the $21^{\text {st }}$ century, electronic learning has become an invaluable technology for teaching, learning and research in business education. According to Ajadi (2008), electronic learning is an innovative approach for delivery electronically mediated, well designed, learner centred and interactive learning environments to anyone, anyplace, anytime by utilizing the internet and digital technologies in the instructional design principles. Naidu (2006) presents electronic learning as incorporating all educational activities that are carried out by individuals or groups working online or offline, and synchronously or asynchronously via networked or standalone computers and other electronic devices. That is, electronic learning facilitates the quick and easy acquisition of business education skills.

Over time, the issue has been on the role electronic learning plays in the acquisition of skills such as word processing, internet and communication. Scholars have identified these skills as useful in the organization and these skills have been given traditional approach before now because of the inadequacy of technological tools and facilities in the environment. With the advent of technology and its subsequent diffusion, researchers are beginning to wonder if these electronic learning facilities are capable of influencing the acquisition of these business education skills. It was upon this premise that the researcher investigated the influence of Electronic learning facilities on the acquisition of business education skills in Edo State.

\section{Purpose of the Study}

The main purpose was to examine business education students' perception of the influence of electronic learning on skill acquisition in Edo State, however the specific purpose were:

1. To examine the extent at which electronic learning influences the acquisition of distributive/marketing skills in business education.

2. To examine the extent to which electronic learning influences the acquisition of entrepreneurial skills in business education

3. To examine the extent to which electronic learning influences the acquisition of teaching skills in business education.

\section{Research Questions}

The following research questions were therefore raised to guide the study;

1. To what extent does electronic learning influences the acquisition of distributive/marketing skills in business education?

2. To what extent does electronic learning influences the acquisition of entrepreneurial skills in business education?

3. To what extent does electronic learning influences the acquisition of teaching skills in business education?

\section{Methodology}

This study utilized the descriptive survey research design since it was basically a detail investigation into the business education students' perception of the influence of electronic learning on skill acquisition in Edo State. The population of this study consists of all final year students of business education in Ambrose Alli University, Ekpoma. The total population was 428 final year students in University of Benin and 137 Ambrose Alli University students in 2016/17 academic session. The systematic random sampling technique was used in selecting a sample size of eighty six (86) business education students which represents twenty percent $(20 \%)$ of the total population of final year business education students in AAU and UNIBEN. The instrument that was used for this study was a structured questionnaire. The questionnaire was used in eliciting information from the respondents and it was titled: Electronic Learning Questionnaire (ELEQ) it was divided into two parts-A and B. Part A consists of the demographic characteristics of the respondents such as sex; while part B consist of 15 opinion statements designed in a 4 point rating scale showing Very High Extent (VHE) High Extent (HE), Low Extent (LE) and Very Low Extent (VLE), and weighted 4, 3, 2, 1 respectively. The Cronbach's alpha was used in ascertaining the reliability of the instrument and it yielded a coefficient of 0.89 . The researcher personally administered the questionnaires to the concerned respondents during their combined 400 level departmental course. The researcher utilized mean and 
standard deviation the data. Any mean value of 2.50 and above was considered as agreed while below 2.50 was considered as disagreed. The Statistical Package for Social Sciences (SPSS) version 22.0 was used in the analysis.

Data Presentation, Analysis and Discussion

This section dealt with the presentation and analysis of data collected and the discussion of findings. The results of the analysis are presented according to the order of the research questions:

Research Question 1: $\quad$ To what extent does electronic learning influences the acquisition of distributive skills in business education?

Questionnaire items $1-5$ were designed to address the research question. The summary of responses is as given in table 1.

Table 1

Mean and Standard Deviation on Electronic learning on Distributive Skill in Business Education

\begin{tabular}{|c|c|c|c|c|}
\hline $\mathbf{S} / \mathbf{N}$ & Items & Mean & SD & Remark \\
\hline 1. & $\begin{array}{l}\text { Electronic learning also influences the distributive } \\
\text { skills embedded in business education. }\end{array}$ & 2.91 & .87 & High Extent \\
\hline 2. & $\begin{array}{l}\text { The distributive skills of business education students } \\
\text { is better enhanced with Electronic learning facilities. }\end{array}$ & 3.13 & .75 & High Extent \\
\hline 3. & $\begin{array}{l}\text { Electronic learning promotes easy assimilation of } \\
\text { distributive skills. }\end{array}$ & 3.09 & .83 & High Extent \\
\hline 4. & $\begin{array}{l}\text { Electronic learning facilities exposes students to } \\
\text { online marketing. }\end{array}$ & 3.31 & .77 & High Extent \\
\hline 5. & $\begin{array}{l}\text { Electronic learning facilities equip business } \\
\text { education students with online advert skills. }\end{array}$ & 3.50 & .74 & High Extent \\
\hline
\end{tabular}

Cluster
Source: Field Survey, (2017)

Table 1 shows that the mean responses ranged from 2.91 to 3.50 while the standard deviation ranged from .74 to .87 , the table revealed that the respondents agreed to all the five items item's as the factors affecting Electronic learning on the acquisition of Distributive skills in Business education in UNIBEN and AAU. Since the cluster mean is 3.19 and it is above the criterion mean value of 2.50, it shows that Electronic learning influences the acquisition of Distributive skills in business education in UNIBEN and AAU.

Research Question 2:

To what extent does electronic learning influences the acquisition of entrepreneurial skills in business education?

Questionnaire items 6-10 were designed to address the research question. The summary of responses is as given in table 2.

Table 2

Mean and Standard Deviation on Electronic learning on Entrepreneurship Skill in Business Education

\begin{tabular}{lllll}
\hline S/N & Items & Mean & SD & Remark \\
\hline 6. & $\begin{array}{l}\text { Electronic learning exposes students to the demands } \\
\text { of self - employment. }\end{array}$ & 3.33 & .74 & High Extent \\
7. & $\begin{array}{l}\text { Electronic learning facilities stimulates business } \\
\text { education students entrepreneurial skills. }\end{array}$ & 2.94 & .80 & High Extent \\
8. & $\begin{array}{l}\text { Electronic learning exposes business education } \\
\text { students to global trend in small scale businesses. }\end{array}$ & 3.15 & .78 & High Extent \\
9. & $\begin{array}{l}\text { Electronic learning facilities makes the acquisition of } \\
\text { entrepreneurial skills easy. }\end{array}$ & .11 & High Extent \\
10. & $\begin{array}{l}\text { Electronic learning has significant effect on the } \\
\text { entrepreneurial skills of students in business } \\
\text { education. }\end{array}$
\end{tabular}

\footnotetext{
Cluster

3.11

$.80 \quad$ High Extent

Source: Field Survey, (2017)

Table 2 shows that the mean responses ranged from 2.94 to 3.33 while the standard deviation ranged from .74 to .87 , the table revealed that the respondents agreed to all the five items item's as the factors affecting Electronic learning on the acquisition of Entrepreneurship skills in Business education in UNIBEN and AAU. Since the cluster mean is 3.19 and it is above the criterion mean value of 2.50, it shows that Electronic learning influences the acquisition of Entrepreneurship skills in business education in UNIBEN and AAU.
} 
Research Question 3:

To what extent does electronic learning influences the acquisition of teaching skills in business education?

Questionnaire items $11-15$ were designed to address the research question. The summary of responses is as given in table 3.

Table 3

Mean and Standard Deviation on Electronic learning on Teaching Skill in Business Education

\begin{tabular}{lllll}
\hline S/N & Items & Mean & SD & Remark \\
\hline 11. & $\begin{array}{l}\text { Electronic learning facilities promotes the } \\
\text { acquisition of teaching skills. }\end{array}$ & .78 & High Extent \\
12. & $\begin{array}{l}\text { Teachers teaching skills are influenced by } \\
\text { Electronic learning and thereby enhancing their } \\
\text { knowledge of internet. }\end{array}$ & .76 & High Extent \\
13. & $\begin{array}{l}\text { Electronic learning facilities enables business } \\
\text { education teachers to be proficient in word } \\
\text { processing skills. } \\
\text { Teachers' use of Electronic learning facilities } \\
\text { enhances their teaching skills in business education. } \\
\text { Students' academic success in business education is } \\
\text { usually influenced by the effective use of Electronic } \\
\text { learning by teachers. }\end{array}$
\end{tabular}

Cluster
Source: Field Survey, (2017)
Table 3 shows that the mean responses ranged from 3.02 to 3.27 while the standard deviation ranged from
.76 to 1.01 , the table revealed that the respondents agreed to all the five items item's as the factors affecting
Electronic learning on the acquisition of teaching skills in Business education in UNIBEN and AAU. Since the
cluster mean is 3.20 and it is above the criterion mean value of 2.50 , it shows that Electronic learning influences
the acquisition of Teaching skills in business education in UNIBEN and AAU.

\section{Discussion of Findings}

The analysis of research questions 1, which shows that Electronic learning, influences the acquisition of distributive skills in business education, corresponds with the findings of Udo, (2012) who found from previous studies (empirical analysis) that distributive skill in business education aids academic performance of students in secondary schools, it also correspond with the finding of Ekpenyong (2012) who conducted a research on business education skill issues of information sharing and communication formed that information sharing been close significance to the impact of distributive skill in business education.

The analysis of research question 2 shows that Electronic learning influence the acquisition of entrepreneurial skills in business education, this however corresponds with the findings of Amado (2013) who stated that entrepreneurial skills is a components of business education programme, that aids and facilities the experience of students, have aids and facilitates the experience of students, have aiding suitable education programmes to help develop entrepreneurial wind sets and company training in entrepreneurship skills are considered critical.

Finally, the analysis of research question 3 shows that Electronic learning influences the acquisition of teaching skills in business education, this corroborates the findings of Okoh, (2003) who stated that teaching is an intentional activity or goal-oriented activity in which a teacher is fostering or seeking to foster in a learner (who has voluntary subjected himself/herself to the teacher) worthwhile dispositions/skills by pedagogical method with the findings of Adesina (2010) who stated that teaching skills is the acquisition of teaching experience for dissemination of information to recipients in this case students of business education.

\section{Conclusion}

On this basis of the findings, it can be concluded that for business education graduates to be able to meet up with the demands of modern day business world, there is need for electronic learning facilities to be used in preparing business education students for the world of work. This will help the students to acquire the necessary skills desirable in the business world.

\section{Recommendation}

In line with the above conclusion, the following recommendations were made.

1. tertiary institutions offering business education need to be provided with electronic learning facilities by 
the appropriate authorities to enhance the preparation of business education students for the world of work.

2. computer and internet studies need to be properly incorporated into business education.

3. students should be allowed to have access to the electronic learning facilities provided in the departments.

4. business education lecturers should engage themselves in continuous training in ICT facilities.

\section{REFERENCES}

Adesina, T. J. (2014). Understanding Business Education. Zaria: Esonaj Publishers.

Adeyomo, S. A. (2009). Understanding and acquisition of entrepreneurial skills: a pedagogical re-orientation for classroom teacher in science education. Journal of Turkish Science Education, 6(3), 57-65

Agomuo, E. E. (2005). Entrepreneurial skills acquisition models for small scale business management. Book of Reading in Business Education: Nigeria Association of Business Educators, 1(1), 58-67.

Agwumezie, F. U. (2013). Resources Management in Business Education Programme: Towards Utilizing the Great Potentials of Women. Business Education Journal, 3(2), 128 - 136.

Ajadi, T. O. (2008). E-Learning and Distance Education in Nigeria. Turkish Online Journal of Distance Education 7 (4): $100-104$.

Aliyu, M. M., (2006). Business Education in Nigeria: Trends and Issues. Ilorin: Goshy Multimedia.

Amodu, T. (2013). Teaching and Learning Methods in Higher Education: A Glimpse of the Future. Reflections on Higher Education, 9, 77-102.

Ekpenyong, L. E. (2012). "Vocational Content in the National Curriculum for Nigerian Secondary Schools: How Industry Can Help?" The Vocational Aspect of Education Vol. XL (106). 57 - 62.

Etesike, C. N. (2010). Skills Acquisition in Nigeria Education System: A Myth or Reality. Journal of Qualitative Education, 6(2), 44-51.

Hisrich, R. D., \& Peters, M. P. (2002). Entrepreneurship. Boston: McGraw Hill http://zunaed.blogspot.com/, (Accessed on: August 4, 2012).

Imeokparia, P. O. \& Ediagbonya, K. (2014). Assessment of Business Education Students' Enrolment Trend in Ambrose Alli University. European Journal of Educational Studies, 6(3), 87-98.

Naidu, S. (2006). E-learning: A Guide Book of Principles, Procedures and Practices. Asia: Common Wealth Education Media Centre for Asia.

Okoh N., (2003). Business Education: Vision and Mission for Sustainable Economy: A Keynote Address. Business Education Journal, 3(2), 1-8.

Okorie. J. U., \& Ezeji, S. C. O. A., (2011). Elements of Guidance, Vocational and Career Education. Onitsha: Summer Educational Publishers Nigeria Limited.

Olagunju, Y. A. (2004). Entrepreneurship small scale business enterprises development in Nigeria. Ibadan: University Press PLC

Udo, M. P., (2012). Gender Dimensions in the Teaching and Learning of VBE in Nigerian Senior Secondary Schools. Unpublished PhD Thesis, University of Leeds, Leeds, England. 